\title{
ODPOWIEDZIALNOŚĆ RODZICÓW ZA BRAK OPIEKI NAD DZIEĆMI
}

Dziecko, zgodnie z art. 92 Kodeksu rodzinnego i opiekuńczego', pozostaje aż do pełnoletności pod władzą rodzicielską. Sprawowanie władzy rodzicielskiej wiąże się z odpowiedzialnością rodziców za opiekę nad dzieckiem. Rodzice nie zawsze jednak w sposób właściwy wywiązują się ze swoich obowiązków wynikających z zadań opiekuńczo-wychowawczych względem dziecka, np. doprowadzają do zaniedbań, pozostawiają dziecko bez właściwej opieki. W konsekwencji moga ponieść odpowiedzialność za narażenie dziecka na niebezpieczeństwo lub za porzucenie.

\section{Władza rodzicielska}

Obowiązek sprawowania opieki nad dzieckiem wynika z art. $95 \S 1$ k.r.o., który wymienia elementy władzy rodzicielskiej. Zdaniem J. Ignatowicza, władza rodzicielska to „zespół obowiązków i praw rodziców względem małoletniego dziecka, mających na celu zapewnienie mu należytej pieczy i strzeżenia jego interesów" ${ }^{\prime 2}$.

* Dr, SWPS Uniwersytet Humanistycznospołeczny.

1 Ustawa z dnia 25 lutego 1964 r. - Kodeks rodzinny i opiekuńczy, tekst jednolity: Dz. U. z 2017 r. poz. 682 z późn. zm. (dalej: k.r.o.).

2 J. Ignatowicz [w:] K. Pietrzykowski (red.), Kodeks rodzinny i opiekuńczy. Komentarz, Warszawa 2012, Legalis; zob. H. Ciepła [w:] K. Piasecki (red.), Kodeks rodzinny i opiekuńczy. Komentarz, Warszawa 2011, s. 728; J. Strzebinczyk [w:] T. Smyczyński (red.), System Prawa Prywatnego, t. 12. Prawo rodzinne i opiekuńcze, Warszawa 2011, s. 233-386. Szerzej o pojęciu władzy rodzicielskiej, zob. K. Hendrych, Wykonywanie władzy rodzicielskiej i kontaktów 
Do odpowiedzialności rodzicielskiej nawiązują również międzynarodowe regulacje prawne. Konwencja z dnia 20 listopada 1989 r. o prawach dziecka ${ }^{3}$ określa w art. 18 ust. 1, że odpowiedzialność rodziców za wychowanie i rozwój dziecka jest wspólna, a w art. 27 ust. 2 mowa jest o głównej odpowiedzialności rodziców za zabezpieczenie warunków życia niezbędnych do rozwoju dziecka. Tak samo ujęto rzecz w Europejskiej konwencji z dnia 25 stycznia 1996 r. o wykonywaniu praw dzieci ${ }^{4}$.

W Rekomendacji Komitetu Ministrów Rady Europy Nr R(84)4 z dnia 28 lutego 1984 r. o odpowiedzialności rodzicielskiej ${ }^{5}$ zdefiniowano tę odpowiedzialność jako

zespół obowiązków i uprawnień, których celem jest zapewnienie moralnego i materialnego dobra dziecka, w szczególności poprzez sprawowanie pieczy nad osobą dziecka, utrzymywanie osobistych kontaktów z dzieckiem, zapewnienie mu wykształcenia, utrzymania, prawnej reprezentacji oraz zarządzanie jego majątkiem ${ }^{6}$.

Do odpowiedzialności rodzicielskiej nawiązuje także rozporządzenie Rady 2201/2003/WE z dnia 27 listopada 2003 r. o jurysdykcji oraz uznawaniu i wykonywaniu orzeczeń w sprawach małżeńskich oraz w sprawach dotyczących odpowiedzialności rodzicielskiej ${ }^{7}-w$ art. 2 pkt 7,

w warunkach istnienia elementu zagranicznego, Warszawa 2016; P.J. Jaros, M. Michalak (oprac.), Prawa dziecka. Dokumenty Organizacji Narodów Zjednoczonych, Warszawa 2015.

3 Konwencja o prawach dziecka, przyjęta przez Zgromadzenie Ogólne Narodów Zjednoczonych dnia 20 listopada 1989 r., Dz. U. z 1991 r. Nr 120, poz. 526 z późn. zm.

4 Europejska Konwencja o wykonywaniu praw dzieci, sporządzona w Strasburgu dnia 25 stycznia 1996 r., Dz. U. z 2000 r. Nr 107, poz. 1128.

5 Rekomendacja $\mathrm{Nr} \mathrm{R}(84) 4 \mathrm{w}$ sprawie odpowiedzialności rodzicielskiej, przyjęta przez Komitet Ministrów Rady Europy 28 lutego 1984 r., [w:] M. Safjan (red.), Standardy Prawne Rady Europy. Teksty i komentarze, t. 1. Prawo rodzinne, Warszawa 1994, s. 201-216.

6 S. Kalus, Zmiany w zakresie orzekania o wtadzy rodzicielskiej i kontaktach $z$ dzieckiem $w$ wyroku rozwodowym w świetle noweli do kodeksu rodzinnego i opiekuńczego - referat wygłoszony na konferencji w Osnabrück w 2011 r., s. 7, za: K. Hendrych, Wykonywanie władzy rodzicielskiej i kontaktów w warunkach istnienia elementu zagranicznego, Warszawa 2016, s. 16; zob. A. Głowacka, Nienależyte sprawowanie opieki. Odpowiedzialność odszkodowawcza opiekuna, „Acta Erasmiana” 2015, t. 10, s. 249-272; J. Szymańczak, Europejska konwencja o wykonywaniu praw dzieci jako kolejny element prawnej ochrony dzieci, „Informacja Biura Studiów i Ekspertyz" 1996, nr 377, s. 1-16.

7 Rozporządzenie Rady 2201/2003/WE z dnia 27 listopada 2003 r. o jurysdykcji oraz uznawaniu i wykonywaniu orzeczeń w sprawach małżeńskich oraz w sprawach dotyczących odpowiedzialności rodzicielskiej, Dz. Urz. UE L 338/1 z 23.12.2003. 
a także Konwencja z dnia 19 października 1996 r. o jurysdykcji, prawie właściwym, uznawaniu, wykonywaniu i współpracy w zakresie odpowiedzialności rodzicielskiej oraz środków ochrony dzieci ${ }^{8}$.

Władzy rodzicielskiej nie można scedować na inne osoby (art. $93 \S 1$ k.r.o.). Przysługuje ona obojgu rodzicom $\mathrm{w}$ takim samym zakresie, co oznacza, że każdemu z nich władza przysługuje w pełnym zakresie, dlatego też na zewnątrz każdy z nich może podejmować działania tak, jakby władza rodzicielska przypadała wyłącznie jemu?

\section{Definicja dziecka}

Zanim zostaną omówione kwestie pozostawiania dziecka samego w domu oraz odpowiedzialności rodziców za brak należytej opieki nad dzieckiem, należy wyjaśnić, kim jest dziecko. Według Konwencji o prawach dziecka, dziecko to każda istota ludzka w wieku poniżej 18 lat, chyba że zgodnie z prawem odnoszącym się do dziecka uzyska ono wcześniej pełnoletność (art. 1 konwencji).

$Z$ art. 1 ust. 1 Europejskiej Konwencji z dnia 25 stycznia 1996 r. o wykonywaniu praw dziecka ${ }^{10}$ wynika, że konwencja ma zastosowanie do dzieci, które nie ukończyły 18 roku życia.

Dziecko, zgodnie z art. 2 ust. 1 ustawy z dnia 6 stycznia 2000 r. o Rzeczniku Praw Dziecka ${ }^{11}$, to każda istota ludzka od poczęcia do osiągnięcia pełnoletności.

Kodeks cywilny ${ }^{12}$ natomiast posługuje się zwrotem "pełnoletni” oraz „małoletni". Pełnoletni jest to osoba, która ukończyła lat 18 (art. 10 § 1 k.c.). Przez zawarcie małżeństwa małoletni uzyskuje pełnoletność i nie traci jej

8 Konwencja o jurysdykcji, prawie właściwym, uznawaniu, wykonywaniu i współpracy w zakresie odpowiedzialności rodzicielskiej oraz środków ochrony dzieci (z dnia 19 października 1996 r.), Dz. Urz. UE L 151/39 z 11.06.2008.

9 Zob. J. Ignatowicz [w:] K. Pietrzykowski (red.), Kodeks rodzinny i opiekuńczy..., s. 866.

10 Ustawa z dnia 10 października 2012 r. o zmianie zakresu obowiązywania Konwencji o prawach dziecka, przyjętej dnia 20 listopada 1989 r., Dz. U. z 2012 r. poz. 1333.

11 Ustawa z dnia 6 stycznia 2000 r. o Rzeczniku Praw Dziecka, tekst jednolity: Dz. U. z 2017 r. poz. 922.

12 Ustawa z dnia 23 kwietnia 1964 r. - Kodeks cywilny, tekst jednolity: Dz. U. z 2019 r. poz. 1145 (dalej: k.c.). 
w przypadku unieważnienia małżeństwa (art. 10 § 2 k.c.). Małoletnim zaś jest osoba, która nie ukończyła 18 lat.

Ustawa z dnia 26 października 1982 r. o postępowaniu w sprawach nieletnich ${ }^{13}$ posługuje się określeniem „nieletni” i pojęcie to obejmuje swoim zakresem trzy kategorie osób:

a) w zakresie zapobiegania i zwalczania demoralizacji nieletnim jest osoba do 18 roku życia;

b) w zakresie postępowania w sprawach o czyny karalne nieletnim jest osoba między 13 a 17 rokiem życia, która dopuściła się takiego czynu;

c) w zakresie wykonywania środków wychowawczych lub poprawczych nieletnim jest osoba, względem której środki te zostały orzeczone, nie dłużej jednak niż do ukończenia przez te osoby lat 21.

Określeniem używanym w niektórych przepisach, np. dotyczących prawa medialnego, jest termin „niepełnoletni” - przeciwieństwo pełnoletniego - czyli osoba, która nie ukończyła lat $18^{14}$.

Kodeks karny ${ }^{15}$ posługuje się dwoma określeniami: „nieletni” i „młodociany". Nieletnim jest osoba, która nie ukończyła lat 17, a za młodocianego uznaje się sprawcę przestępstwa, który popełnił je przed ukonczeniem 21 roku życia, a w czasie orzekania przez sąd I instancji ma nie więcej niż 24 lata.

\section{Regulacje związane z samodzielnym przemieszczaniem się dziecka i pozostawaniem $\mathrm{w}$ domu}

Ustawa z dnia 20 czerwca 1997 r. - Prawo o ruchu drogowym ${ }^{16} \mathrm{w}$ art. 43 ust. 1 stanowi, iż dziecko w wieku do 7 lat może korzystać z drogi tylko

13 Ustawa z dnia 26 października 1982 r. o postępowaniu w sprawach nieletnich, tekst jednolity: Dz. U. z 2018 r. poz. 969 (dalej: u.p.s.n.).

14 Zob. M. Kaczmarek, Standardy prawa rodzinnego - zagadnienia prawne dotyczace dziecka i rodziny. Materiaty szkoleniowe dla osób pracujących z dzieckiem i rodzina, http:/ / www.frs. pl/docs/pr_kaczmarek.pdf [dostęp: 13.11.2018 r.].

15 Ustawa z dnia 6 czerwca 1997 r. - Kodeks karny, tekst jednolity: Dz. U. z 2018 r. poz. 1600 (dalej: k.k.).

16 Ustawa z dnia 20 czerwca 1997 r. - Prawo o ruchu drogowym, tekst jednolity: Dz. U. z 2018 r. poz. 1990 z późn. zm.; zob. J. Brylak, Ochrona prawna bezpieczeństwa w ruchu drogowym, Warszawa 2018. 
pod opieką osoby, która osiągnęła wiek co najmniej 10 lat. Nie dotyczy to strefy zamieszkania. Oznacza to, że dziecko samodzielnie po drodze może poruszać się jeżeli ukończyło 7 lat. Natomiast poniżej 7 roku życia może przebywać na drodze pod opieką innego dziecka pod warunkiem ukończenia przez niego 10 lat.

Należy jednak wyjaśnić czym jest „droga” i „strefa zamieszkania”. Prawo o ruchu drogowym w art. 2 definiuje „drogę" jako wydzielony pas terenu składający się z jezdni, pobocza, chodnika, drogi dla pieszych lub drogi dla rowerów, łącznie z torowiskiem pojazdów szynowych znajdującym się $w$ obrębie tego pasa, przeznaczony do ruchu lub postoju pojazdów, ruchu pieszych, jazdy wierzchem lub pędzenia zwierząt. Natomiast "strefa zamieszkania" to obszar obejmujący drogi publiczne ${ }^{17}$ lub inne drogi, na którym obowiązują szczególne zasady ruchu drogowego, a wjazdy i wyjazdy oznaczone są odpowiednimi znakami drogowymi.

Samodzielna podróż dziecka nie znajduje regulowania $\mathrm{w}$ jakiejkolwiek ustawie czy rozporządzeniu. Przewoźnicy kwestie te określają w regulaminach.

W przypadku lotu samolotem większość przewoźników umożliwia za dodatkową opłatą osobistą opiekę pokładowej obsługi nad dzieckiem. Przykładowo LOT w punkcie 8.2. regulaminu określa:

Przewoźnik dołoży starań aby ułatwić podróżowanie osobom chorym, niepełnosprawnym, dzieciom bez opieki oraz kobietom w ciąży. Przyjęcie do przewozu dzieci bez opieki, osób chorych, osób niepełnosprawnych lub kobiet $\mathrm{w}$ ciąży może być uzależnione od wcześniejszego uzgodnienia z przewoźnikiem warunków dokonania takiego przewozu, zgodnie z obowiązującym prawem. Szczegółowe zasady dotyczące przewozu osób, o których mowa w zdaniach poprzedzających można znaleźć na stronie internetowej przewoźnika www.lot.com. LOT oferuje dla dzieci do 5 roku życia podróżujących samodzielnie specjalną asystę ${ }^{18}$.

17 Definicja „drogi publicznej” podana jest w art. 1 ustawy z dnia 21 marca 1985 r. o drogach publicznych (tekst jednolity: Dz. U. z 2018 r. poz. 2068 z późn. zm.) i jest to droga zaliczona na podstawie niniejszej ustawy do jednej z kategorii dróg, z której może korzystać każdy, zgodnie z jej przeznaczeniem, z ograniczeniami i wyjątkami określonymi w tej ustawie lub innych przepisach szczególnych. Drogi publiczne dzielą się na drogi ogólnodostępne i drogi o ograniczonej dostępności, w tym autostrady i drogi ekspresowe (art. 3 ustawy).

18 Ogólne warunki przewozu pasażerów i bagażu stosowane w Polskich Liniach Lotniczych LOT S.A. wydane na podstawie art. 205 ust. 2a ustawy z dnia 3 lipca 2002 r. Prawo 
Jak czytamy na stronie LOT w przypadku dzieci do 5 roku życia: „Dedykowana stewardessa towarzyszy Twojemu dziecku od momentu odprawy biletowo-bagażowej aż do chwili odebrania dziecka przez wyznaczoną osobę dorosłą na lotnisku docelowym"19. Usługa jest dodatkowo płatna. Istnieje również specjalna asysta dla dzieci w wieku od 5 do 12 lat (usługa również jest dodatkowo płatna); „Opiekę sprawuje członek personelu pokładowego LOT oraz pracownicy obsługi pasażerskiej, kolejno wyznaczeni w procesie obsługi naziemnej" ${ }^{20}$.

W przypadku młodzieży w wieku od 12 do 17 lat LOT umożliwia podróżowanie samodzielnie bez asysty. Jednak na specjalne życzenie rodziców lub opiekunów, młodzież w tym wieku może podróżować pod opieką członka personelu pokładowego. Opieka zostanie zorganizowana analogicznie jak dla dzieci w wieku od 5 do 12 lat.

Podobne zasady panują m.in. w Lufthansie (w ciągu roku aż 70 tys. dzieci podróżuje tymi liniami samodzielnie $)^{21}, \mathrm{KLM}^{22}$, Air France ${ }^{23}$, Emirates ${ }^{24}$.

Dzieci poniżej 13 roku życia mogą podróżować liniami komunikacji dalekobieżnej wyłącznie z opiekunem, a pomiędzy 13 a 18 rokiem życia, mogą podróżować samodzielnie pod warunkiem posiadania druku „Oświadczenia o przewozie osoby nieletniej”, wypełnionego przez rodzica lub opiekuna prawnego ${ }^{25}$. Niektórzy przewoźnicy

lotnicze (Dz. U.02.130.1112), https:/ / www.lot.com/pl/pl/conditions-of-carriage [dostęp: 13.11.2018 r.].

19 Podróż dziecka bez opiekuna, https://www.lot.com/pl/pl/podroz-dziecka-bez-opiekuna [dostęp: 13.11.2018 r.].

20 Tamże.

${ }^{21}$ Zob. Dzieci podróżujace samodzielnie - mali pasażerowie to wielka sprawa!, https:// www.lufthansa.com/pl/pl/dzieci-podrozujace-same [dostęp: 14.01.2019 r.].

${ }_{22}$ Zob. Ustuga asysty dla dzieci podróżujących bez opieki (Unaccompanied Minor), https:/ / www.klm.com/travel/pl_pl/prepare_for_travel/travel_planning/children/umnr_yp_ framed.htm [dostęp: 14.01.2019 r.].

23 Zob. Kids Solo, https://www.airfrance.pl/PL/pl/common/guidevoyageur/assistance/enfant_seul_um.htm [dostęp: 14.01.2019 r.].

24 Zob. Czy moje dziecko może samo lecieć liniami Emirates?, https://www.emirates. $\mathrm{com} / \mathrm{pl} /$ polish/help/faq/193411/can-my-child-travel-alone-on-an-emirates-flight [dostęp: 14.01.2019 r.]; Podróż dziecka bez opiekuna w samolocie, https://www.esky.pl/porady-dla-podroznych/loty/dziecko-w-samolocie/podroz-dziecka-bez-opiekuna-w-samolocie [dostęp: 14.01.2019 r.].

25 Regulamin przewozów komunikacji dalekobieżnej „POLONUS” obowiązujący w Przedsiębiorstwie Komunikacji Samochodowej „POLONUS” w Warszawie spółka akcyjna wydany zgodnie z art. 4 ustawy z dnia 15 listopada 1984 r. Prawo przewozowe (tekst 
obniżają wiek dziecka do 12 lat w przypadku wymogu podróżowania samodzielnego ${ }^{26}$.

Najbardziej liberalny jest przewoźnik FlixBus, w którego regulaminie znajduje się informacja:

11.2. Dzieci i osoby małoletnie poniżej 10 roku życia mogą być przewożone na trasach krajowych i międzynarodowych wyłącznie, jeśli podczas podróży towarzyszy im osoba dorosła. 11.3 Dzieci i osoby małoletnie w wieku od 10 do 14 lat mogą podróżować bez opiekuna tylko, jeśli ich opiekun prawny pisemnie potwierdzi $\mathrm{w}$ procesie rezerwacji, że osoba małoletnia jest zdolna do odbycia takiej podróży i może ją odbyć samodzielnie i bez opieki. Firma FlixMobility, spółkami Flix i ich firmy partnerskie nie przejmują obowiązku nadzoru nad osobą małoletnią. Dzieci nie mogą podróżować samodzielnie w przypadku połączeń nocnych oraz zakładających przekroczenie granicy kraju. Ponadto dzieci nie mogą samodzielnie podróżować na trasach z przesiadkami. 11.4 Młodzież od 15 roku życia może podróżować samodzielnie. W przypadku połączeń międzynarodowych opiekunowie muszą się upewnić, że nastolatkowe mają przy sobie wszystkie dokumenty i dowody tożsamości, które są niezbędne do przekroczenia granicy (por. punkt 11.2) ${ }^{27}$.

Część przewoźników uznaje, że samodzielna podróż dziecka komunikacją miejską możliwa jest dopiero od 13 roku życia. Jako podstawę prawną powołują przepisy Kodeksu cywilnego, który określa, że po ukończeniu 13 roku życia nabywa się ograniczona zdolność do czynności prawnych m.in. do zakupu biletu lub jego skasowania, czyli zawarcia umowy przewozu osób. Innym czynnikiem branym pod uwagę jest obiektywna ocena czy trzynastolatek posiada wystarczającą zaradność, aby bezpiecznie dotrzeć tam, dokąd zmierza.

Regulamin przewozu środkami lokalnego transportu zbiorowego w m.st. Warszawie nie zawiera regulacji dotyczących przewozu dzieci.

jedn.: Dz. U. z 2000 r. Nr 50, poz. 601 z późn. zm.) (komunikacja dalekobieżna) oraz dla wykonania obowiązku nałożonego postanowieniem art. 18 b. ust. 1 pkt. 5 ustawy z dnia 6 września 2001 r. o transporcie drogowym (Dz. U. z 2004 r. Nr 204, poz. 2088 z późniejszymi zmianami), https:// pkspolonus.pl/regulaminy/przewozow [dostęp: 13.11.2018 r.].

26 Regulamin przewozu osób krajowymi liniami autokarowymi Albatros Sp. z o.o., https://dworzeconline.pl/static/default/img/regulamin/regulamin_albatros.pdf; inne regulaminy:https:/ / dworzeconline.pl/info/strefa-pasazera/regulamin-przewozow-przewoznikow [dostęp: 13.11.2018 r.].

27 Dla spólek Flix: Ogólne warunki przewozu, https://www.flixbus.pl/ogolne-warunki-przewozu-firmy-flixbus [dostęp: 13.11.2018 r.]. 
Zgodnie z regulaminem, pasażerem jest osoba, która zawarła umowę przewozu zgodnie z warunkami określonymi w $\S 4$, który określa moment zawarcia umowy przewozu. Zawarcie umowy przewozu następuje wraz $\mathrm{z}$ wejściem pasażera do pojazdu, a w metrze - do strefy biletowej metra ${ }^{28}$. Osoba, która posiada Kartę Ucznia (musi spełnić warunek, że mieszka i uczęszcza do szkoły w Warszawie) ma prawo do bezpłatnych przejazdów ${ }^{29}$. Zatem dziecko jest pasażerem. Dotyczy to dzieci, które skończyły 7 lat i zgodnie z przepisami mogą poruszać się samodzielnie po ulicy.

Regulamin PKP nie określa zasad podróży dziecka samodzielnie. Zatem decyzja należy do rodziców, którzy odpowiadają za dziecko aż do momentu osiągnięcia pełnoletności. Trudno jednak uznać, że brak stosownych regulacji umożliwia samodzielną podróż pociągiem dziecka np. w wieku 8 lat. Rodzice powinni kierować się rozsądkiem i sugerować się wytycznymi zawartymi u innych przewoźników, zwłaszcza międzymiastowymi lub międzynarodowymi oraz przepisami Kodeksu cywilnego, dotyczących ograniczonej zdolności do czynności prawnych, w których podawany jest wiek 13 lat.

Do innych sposobów przemieszczania się zalicza się korzystanie $\mathrm{z}$ windy lub ruchomych schodów. W regulaminach oraz $\mathrm{w}$ informacjach umieszczanych w windach znajdują się określone wskazówki np.: „Dzieci do lat 12-nastu mogą korzystać z windy wyłącznie pod opieką dorosłych" albo „Dzieci do lat 10 bez opieki dorosłych nie mogą korzystać z ruchomych schodów".

Brak przyjętych jednolitych zasad przewoźników wprowadza chaos. Rodzice zanim zgodzą się na samodzielną podróż dziecka muszą zapoznać się z regulaminem danego przewoźnika. Jak można zauważyć

28 Regulamin przewozu środkami lokalnego transportu zbiorowego w m.st. Warszawie, Zarządzenie nr 790/2016 Prezydenta m.st. Warszawy z dnia 27 maja 2016 r., http:/ / www.ztm.waw.pl/?c=134\&l=1 [dostęp: 13.11.2018 r.].

29 Karta Ucznia jest uprawnieniem do bezpłatnych przejazdów wynikających z Uchwały nr XLVII/1138/2017 RADY MIASTA STOŁECZNEGO WARSZAWY z dnia 6 kwietnia 2017 r. zmieniająca uchwałę w sprawie ustalenia cen za usługi przewozowe środkami lokalnego transportu zbiorowego w m.st. Warszawie. Na podstawie Karty Ucznia uprawnienie do bezpłatnych przejazdów przysługuje: uczniom szkół podstawowych i gimnazjów działających na terenie m.st. Warszawy, a także uczniom klas gimnazjalnych w szkołach innego typu działających na terenie m.st. Warszawy; uczniom szkół podstawowych i gimnazjów zamieszkujących na terenie m.st. Warszawy, a także uczniom klas gimnazjalnych w szkołach innego typu zamieszkujących na terenie m.st. Warszawy. Na temat Karty Ucznia, zob. http:/ / www.ztm.waw.pl/?c=697\&l=1 [dostęp: 13.11.2018 r.]. 
regulaminy poszczególnych przewoźników nie są ani w zgodzie z Kodeksem cywilnym, gdzie w kwestii ograniczonej zdolności do czynności prawnych wskazany jest wiek 13 lat, ani w zgodzie z przepisami prawa ruchu drogowego czy Kodeksu wykroczeń ${ }^{30}$, gdzie w art. 89 k.w. wskazany jest wiek 7 lat, jako odpowiedni do samodzielnego poruszania się po drodze.

W przypadku przebywania samego dziecka w domu brak jest regulacji prawnych. Można rozpatrywać różne sytuacje: gdy dziecko zostaje samo w domu w ciągu dnia, w ciągu nocy, od jakiego wieku można pod opieką starszego rodzeństwa pozostawić młodszego brata, siostrę w dzień, w nocy. Jaka jest zatem odpowiednia granica wieku? Zdaniem psychologów jest to 10 lat. Organizacje działające na rzecz praw dziecka uważają, że większość trzynastolatków nie jest gotowa zostać w domu bez opieki, a dzieci starszych o 2-3 lata nie powinno zostawiać się samych na noc. Osoby niemające ukończonych 15 lat, nie są w stanie same pokierować swoim zachowaniem oraz nie potrafią troszczyć się o siebie, czy też nie są w pełni dojrzałe psychofizycznie. Uznano, że tak wyznaczona granica jest zasadna, bowiem starsi małoletni są w stanie zadbać o siebie, a pomimo postępującej akceleracji małoletnich, nie powinno się jej też obniżać31.

Brak przepisów określających jaki wiek jest odpowiedni do samodzielnego pozostawienia dziecka $\mathrm{w}$ domu - czy będzie to 7 lat, 13 czy jeszcze inny wiek - powoduje, że rodzice pozostawiając dziecko bez opieki powinni kierować się rozsądkiem. Zanim rodzic podejmie decyzję, powinien odpowiedzieć sobie na kilka pytań:

1) Czy jest rzeczywiście taka konieczność?

2) Czy dziecko temu podoła?

3) Czy dziecko jest właściwie poinformowane? Czy zna numery telefonów alarmowych, lub czy wie, gdzie te numery są zapisane? Czy rozmawialiście, jak powinno zachować się w sytuacjach kryzysowych, czy wie, że nie wolno otwierać drzwi nieznajomym, nie używać zapałek, nie kręcić pokrętłami z gazem, nie wychylać się przez okno a w razie czego, że może iść do sąsiadki?

4) Czy w ogóle można wyjść z domu? W jakim wieku jest dziecko?

30 Ustawa z dnia 20 maja 1971 r. - Kodeks wykroczeń, tekst jednolity: Dz. U. z 2019 r. poz. 821 z późn. zm. (dalej: k.w.).

31 Zob. Sam w domu! Od jakiego wieku dziecko może zostać bez opieki?, https:/ / www.familie.pl/artykul/Sam-w-domu-Od-jakiego-wieku-dziecko-moze-zostac-bez-opieki,12164,2. html [dostęp: 13.11.2018 r.]. 
5) Czy potrafisz przewidywać? ${ }^{32}$

W 2017 r. przeprowadzono ankietę, w której 714 osobom zadano pytanie, czy zdarza ci się zostawić dziecko bez opieki w domu. Pozytywnej odpowiedzi udzieliło $14 \%$ ankietowanych, ale z zastrzeżeniem, że tylko w sytuacji, kiedy idą do skrzynki na listy albo do sąsiadki; $19 \%$ - bardzo rzadko, jeśli muszą pilnie wyskoczyć po coś do osiedlowego sklepu; 34\% tak, ale nie dłużej niż 1-2 godziny; 9\% - tak, ale uprzedzają sąsiadkę, żeby sprawdzała, czy nie dzieje się nic niepokojącego; natomiast $24 \%$ - nigdy, nie wyobrażają sobie, żeby ich dziecko nie miało opieki ${ }^{33}$.

W raporcie przygotowanym przez Powszechny Zakład Ubezpieczeń wzięło udział 3600 rodziców oraz 1073 dzieci. Wynika z niego, że 12\% przedszkolaków zostaje sama w domu; 50\% dzieci w wieku 7-10 lat zostaje sama w domu, a $20 \%$ dzieci w wieku wczesnoszkolnym bawi się samo po zmroku poza domem ${ }^{34}$.

\section{Odpowiedzialność karna rodziców za brak należytej opieki nad dzieckiem}

Obowiązujące w Polsce przepisy prawa karnego oraz prawa wykroczeń penalizują bezpośrednio lub pośrednio niektóre przejawy naruszenia obowiązków rodzicielskich ${ }^{35}$ i przewidują możliwość pociągnięcia rodziców lub opiekunów do odpowiedzialności za brak należytej opieki nad dzieckiem, którego skutkiem może być narażenie dziecka na niebezpieczeństwo. Przykładem może być sytuacja, w której dziecko poniżej lat 7 narażone jest na niebezpieczeństwo: gdy rodzice pozostawią dziecko samo w domu, przebywa ono bez opieki na ulicy lub pozostaje samo w późnych godzinach wieczornych ${ }^{36}$.

32 Tamże.

33 Zob. W. Stolarska, Od kiedy dziecko może zostać samo w domu?, https:/ / dziecko.trojmiasto.pl/Od-kiedy-dziecko-moze-zostac-samo-w-domu-n115447.html [dostęp: 13.11. 2018 r.].

34 Zob, Powszechny Zakład Ubezpieczeń, Wspótczesny świat dziecka. Diagnoza, https:/ / niestraszki.pzu.pl/files/raport_pzu_bezpieczne_dziecko.pdf [dostęp: 13.11.2018 r.].

35 Na podstawie poprzedniego stanu prawnego, zob. A. Grześkowiak, Prawna odpowiedzialność rodziców za zaniedbania wychowawcze, „Ruch Prawniczy, Ekonomiczny i Socjologiczny" 1985, z. 1, s. 111-128.

36 Zob. Z. Wrona, Odpowiedź podsekretarza stanu w Ministerstwie Sprawiedliwości - z upoważnienia ministra - na zapytanie nr 4059 w sprawie odpowiedzialności rodziców i opiekunów 
Obowiązek opieki lub troszczenia się o dziecko może wynikać z ustawy (art. $95 \S 1$ i art. $96 \S 1$ k.r.o.), decyzji sądu (np. opiekun prawny powołany na podstawie art. $145 \S 1$ k.r.o.), a nawet $\mathrm{z}$ umowy (np. obowiązki opiekunki lub wychowawczyni, których opiece rodzice powierzyli dziecko).

Zaniedbywanie dziecka to brak zapewnienia odpowiednich warunków do rozwoju dziecka w sferze zdrowotnej, edukacyjnej i emocjonalnej odpowiedniego odżywiania, schronienia i bezpieczeństwa (w ramach środków dostępnych rodzicom lub opiekunom) i w następstwie powodujące lub mogące powodować uszczerbek na zdrowiu dziecka lub zaburzenie rozwoju psychicznego, moralnego lub społecznego. Wyróżnia się zaniedbanie fizyczne (ekonomiczne, zdrowotne), emocjonalne, edukacyjne (intelektualne) $)^{37}$.

Pozostawienie dziecka samego w domu lub na ulicy, zwłaszcza poniżej lat 7, może stanowić dla niego narażenie na niebezpieczeństwo utraty życia albo ciężkiego uszczerbku na zdrowiu. Rodzic lub opiekun może za takie zachowanie ponieść odpowiedzialność karną określoną w art. 160 k.k. ${ }^{38}$ Rodzic traktowany jest jako gwarant, tj. osoba na której ciąży szczególny obowiązek opieki nad narażonym na niebezpieczeństwo dzieckiem, a w związku z tym poniesie surowszą odpowiedzialność karną za popełnienie przestępstwa typu kwalifikowanego (art. $160 \S 2$ k.k.), również w sytuacji, gdy działa nieumyślnie. Wystarczającą przesłanką poniesienia odpowiedzialności karnej jest sam fakt wystąpienia bezpośredniego niebezpieczeństwa, które zagraża życiu dziecka albo może doprowadzić do ciężkiego uszczerbku na zdrowiu - nie musi nastąpić skutek, wystarczające jest samo zagrożenie, które powinno być realne.

prawnych za dzieci, często będace ofiarami ich nierozwagi i braku odpowiedzialności, Warszawa, 17 czerwca 2009 r., http://orka2.sejm.gov.pl/IZ6.nsf/main/2D0DB8A3 [dostęp: 13.11.2018 r.]; System opieki nad małoletnimi w Republice Irlandii (stan prawny na dzień 1 kwietnia 2014 r.), https://www.msz.gov.pl/resource/966a55f8-56cb-4f8b-bc40-4fa259be1861:JCR [dostęp: 13.11.2018 r.].

37 Zob. Report of the Consultation on Child Abuse Prevention [Raport z konsultacji nad zapobieganiem krzywdzeniu dzieci], Światowa Organizacja Zdrowia, Genewa 1999, http://fdds. pl/baza_wiedzy/zaniedbywanie-dzieci/ [dostęp: 13.11 .2018 r.].

38 Zob. K. Wiak [w:] A. Grześkowiak, K. Wiak (red.), Kodeks karny. Komentarz, Warszawa 2012, s. 793-794; M. Szwarczyk [w:] T. Bojarski, A. Michalska-Warias, J. Piórkowska-Flieger, M. Szwarczyk, Kodeks karny. Komentarz, Warszawa 2009, s. 311-314; J. Kosonoga [w:] R.A. Stefański (red.), Kodeks karny. Komentarz, Warszawa 2018, s. 993-1000. 
Kolejnym przestępstwem możliwym do popełnienia przez rodziców jest przestępstwo porzucenia określone w art. 210 k.k., który stanowi:

§ 1. Kto wbrew obowiązkowi troszczenia się o małoletniego poniżej lat 15 albo o osobę nieporadną ze względu na jej stan psychiczny lub fizyczny osobę tę porzuca, podlega karze pozbawienia wolności od 3 miesięcy do lat 5 .

§ 2. Jeżeli następstwem czynu jest śmierć osoby określonej w § 1, sprawca podlega karze pozbawienia wolności od lat 2 do $12^{39}$.

Przepis ten ma na celu ochronę bezpieczeństwa i życia m.in. dziecka. Zdaniem Sądu Najwyższego porzucenie oznacza „pozostawienie osoby, nad którą miała być roztoczona opieka, własnemu losowi, przy czym chodzi tu nie tylko o zaniechanie sprawowania opieki nad osobą małoletnią lub nieporadną, lecz także o uniemożliwienie takiej osobie udzielenia natychmiastowego wsparcia" 40 . Warto zwrócić uwagę, że w chwili porzucenia dziecko nie musi znajdować się w niebezpieczeństwie. To właśnie porzucenie może doprowadzić do zagrożenia.

Przestępstwo porzucenia popełnione jest w sytuacji, gdy rodzic wyzbył się opieki nad dzieckiem z zamiarem trwałym, a nie jedynie krótkotrwałym zaniechaniem troski o nie.

Z danych statystycznych policji wynika, że w ostatnich latach liczba przestępstw $z$ art. 210 k.k. maleje ${ }^{41}$.

Tabela 1. Liczba stwierdzonych przestępstw z art. $210 \S 1$ i 2 k.k.

\begin{tabular}{|c|c|c|}
\hline Rok & Liczba wszczętych postępowań & Liczba stwierdzonych przestępstw \\
\hline 2016 & 46 & 22 \\
\hline 2015 & 44 & 10 \\
\hline 2014 & 57 & 12 \\
\hline 2013 & 42 & 13 \\
\hline 2012 & 66 & 16 \\
\hline 2011 & 60 & 32 \\
\hline 2010 & 70 & 38 \\
\hline
\end{tabular}

39 S. Hypś [w:] A. Grześkowiak, K. Wiak (red.), Kodeks karny ..., s. 964-969; M. Szwarczyk [w:] T. Bojarski, A. Michalska-Warias, J. Piórkowska-Flieger, M. Szwarczyk, Kodeks karny..., s. 438-439; J. Kosonoga [w:] R.A. Stefański, Kodeks karny ..., s. 1373-1377; A. Kilińska-Pękacz, Przestępstwo porzucenia dziecka, „Prokuratura i Prawo” 2016, nr 4, s. 22-34.

40 Uchwała Sądu Najwyższego z dnia 4 czerwca 2001 r., V KKN 94/99, LEX nr 49445.

${ }^{41}$ Przestępstwa przeciwko rodzinie i opiece (206-211), http://statystyka.policja.pl/st/ kodeks-karny/przestepstwa-przeciwko-7/63510,Porzucenie-maloletniego-albo-osoby-nieporadnej-art-210.html [dostęp: 13.11.2018 r.]. 


\begin{tabular}{|c|c|c|}
\hline Rok & Liczba wszczętych postępowań & Liczba stwierdzonych przestępstw \\
\hline 2009 & 106 & 37 \\
\hline 2008 & 127 & 46 \\
\hline 2007 & 149 & 79 \\
\hline 2006 & 165 & 95 \\
\hline 2005 & 113 & 72 \\
\hline 2004 & 140 & 59 \\
\hline 2003 & 120 & 86 \\
\hline 2002 & 124 & 66 \\
\hline 2001 & 159 & 76 \\
\hline 2000 & 138 & 71 \\
\hline 1999 & 109 & 47 \\
\hline
\end{tabular}

Dane te mogą napawać optymizmem, ale zauważyć należy, że jednak jest to krzywdzenie dziecka. Dla porównania w 2015 r. w Anglii aresztowano 510 rodziców za pozostawienie dzieci samych $\mathrm{w}$ domu $\mathrm{u}^{42}$.

Przepisy Kodeksu wykroczeń również penalizują sytuacje związane $\mathrm{z}$ pozostawieniem małoletniego do lat 7 bez opieki. Jak wynika $\mathrm{z}$ art. 82 $\S 6$ k.w. pozostawienie dziecka do lat $7 \mathrm{w}$ okolicznościach, w których istnieje prawdopodobieństwo wzniecenia przez niego pożaru stanowi odpowiedzialność osoby, która dopuściła się pozostawienia dziecka bez opieki w szczególności z łatwym dostępem do zapałek czy materiałów łatwopalnych ${ }^{43}$.

Kodeks wykroczeń określa, że wykroczeniem jest sytuacja, gdy osoba mająca obowiązek opieki lub nadzoru nad małoletnim do lat 7, dopuszcza do przebywania małoletniego na drodze publicznej lub na torach pojazdu szynowego (art. 89 k.w.). Za czyn ten grozi kara grzywny albo kara nagany. Słusznie zauważa M. Bojarski i W. Radecki:

Nie jest konieczne wykazanie, że przebywanie dziecka na drodze publicznej lub na torach pojazdu szynowego sprowadziło zagrożenie, gdyż to ustawodawca założył, że dopuszczenie do przebywania dziecka na drodze publicznej lub na torach pojazdu szynowego jest zawsze niebezpieczne. Jeżeli

42 Zob. M. Kwiatek, 510 rodziców zostało aresztowanych za pozostawienia dzieci samych w domu w 2015 roku, http:/ / www.anglia.today/dziecko/510-rodzicow-zostalo-aresztowanych-za-pozostawienie-dzieci-samych-w-domu-w-2015-roku [dostęp: 13.11.2018 r.].

43 Zob. M. Bojarski, W. Radecki, Kodeks wykroczeń. Komentarz, Warszawa 2013, s. 544576; A. Kilińska-Pękacz, Ochrona dzieci w kodeksie wykroczeń, „Studia z Zakresu Prawa, Administracji i Zarządzania Uniwersytetu Kazimierza Wielkiego w Bydgoszczy" 2012, t. 1, s. 205-218. 
pozostawienie dziecka było przyczyną wypadku drogowego, nie jest wykluczona odpowiedzialność pozostawiającego za przestępstwo ${ }^{44}$.

Rodzice mogę również ponieść odpowiedzialność za rażące naruszenie obowiązków wynikających z władzy rodzicielskiej, przez co dopuszczają do popełnienia przez nieletniego czynu zabronionego przez ustawę jako przestępstwo, $\mathrm{w}$ tym i przestępstwo skarbowe, wykroczenie lub wykroczenie skarbowe i wskazującego na demoralizację nieletniego (art. 105 k.w.). Wykroczenie zagrożone jest sankcją kary grzywny albo kary nagany. Istotne dla znamion tego wykroczenia jest stwierdzenie, czy czyn popełniony przez nieletniego wskazuje na realną jego demoralizację. W praktyce należy ustalić, czy zaniedbania ze strony rodziców były poważne, rażące i ewidentnie wpływające na zachowanie nieletniego ${ }^{45}$.

Sam fakt dopuszczenia przez rodzica, który ma obowiązek opieki lub nadzoru nad małoletnim do lat 7 do przebywania w okolicznościach niebezpiecznych dla zdrowia tego dziecka stanowi wykroczenie zagrożone karą grzywny albo karą nagany (art. 106 k.w.). Przykładem takiego zachowania może być dopuszczenie takiej osoby do kąpieli w rzece bez odpowiedniego nadzoru.

Dla odpowiedzialności rodzica wystarczające jest samo niedopełnienie obowiązku jaki na nim spoczywa. Zatem nie jest wymagany skutek w postaci uszkodzenia ciała czy rozstroju zdrowia. Również dla bytu wykroczenia ważne jest, aby małoletni nie osiągnął wieku 7 lat. Jeżeli sytuacja taka dotyczy dziecka powyżej 7 roku życia i nie istnieją okoliczności, na podstawie których można uznać, że dziecko jest inną osobą niezdolną rozpoznać lub obronić się przed niebezpieczeństwem, to nie stanowi to wykroczenia.

${ }_{44}$ M. Bojarski, W. Radecki, Kodeks wykroczeń..., s. 654; zob. J. Brylak, Pozostawienie dziecka na drodze (art. 89 kw), [w:] J. Brylak, Ochrona prawna bezpieczeństwa w ruchu drogowym, Warszawa 2018, Legalis.

45 Zob. Z. Sienkiewicz, Kilka uwag o wykroczeniu z art. 105 k.w., "Zagadnienia Wykroczeń" 1985, nr 4/5, s. 45-50; D. Egierska, Zapobieganie demoralizacji nieletnich (Wokót art. 105 k.w.), „Zagadnienia Wykroczen" 1973, nr 1, s. 65-68; M. Kalitowski, Kodeks wykroczeń a ochrona nieletniego i małoletniego, "Zagadnienia Wykroczeń” 1972, nr 2, s. 44-54; tenże, Ochrona dziecka w kodeksie wykroczeń (Z badań nad wykroczeniami, których popetnienie wiąze się z osoba nieletniego lub matoletniego), "Zagadnienia Wykroczeń" 1979, nr 1, s. 1-8; J. Kosonoga, Glosa do wyr. SN z 3.4.2008 r., IV KK 471/07, „Wojskowy Przegląd Prawniczy” 2010, nr 1, s. $143-150$. 
W przypadku uzasadnionego podejrzenia popełnienia przez rodziców opisanych powyżej przestępstw lub wykroczeń pozwala organom ścigania na wszczęcie i przeprowadzenie postępowania. Oczywiście każda sprawa analizowana jest indywidualnie.

Wskazać również należy na art. 23 Kodeksu postępowania karnego ${ }^{46}$, który nakłada na sąd lub prokuratora obowiązek zawiadomienia sądu rodzinnego o celowości rozważenia orzeczenia środków przewidzianych $\mathrm{w}$ przepisach o postępowaniu w sprawach nieletnich oraz w Kodeksie rodzinnym i opiekuńczym. Chodzi o sytuację, gdy prowadzone jest postępowanie $\mathrm{w}$ sprawie o przestępstwo popełnione na szkodę małoletniego, we współdziałaniu z małoletnim lub w okolicznościach, które mogą świadczyć o demoralizacji małoletniego albo o gorszącym wpływie na niego. Sięganie po kary lub środki karne w stosunku do rodziców powinno być ostatecznością. Sąd opiekuńczy w przypadku powzięcia informacji o nieprawidłowościach w wykonywaniu władzy rodzicielskiej może wydać stosowne zarządzenie lub postanowienia w sytuacji, gdy dobro dziecka jest zagrożone. Na podstawie art. 109 § 2 k.r.o. sąd opiekuńczy może m.in.:

1) zobowiązać rodziców oraz małoletniego do określonego postępowania, w szczególności do pracy z asystentem rodziny, realizowania innych form pracy z rodziną, skierować małoletniego do placówki wsparcia dziennego, określonych $\mathrm{w}$ przepisach o wspieraniu rodziny i systemie pieczy zastępczej lub skierować rodziców do placówki albo specjalisty zajmujących się terapią rodzinną, poradnictwem lub świadczących rodzinie inną stosowną pomoc z jednoczesnym wskazaniem sposobu kontroli wykonania wydanych zarządzeń;

2) określić, jakie czynności nie mogą być przez rodziców dokonywane bez zezwolenia sądu, albo poddać rodziców innym ograniczeniom, jakim podlega opiekun;

3) poddać wykonywanie władzy rodzicielskiej stałemu nadzorowi kuratora sądowego;

4) skierować małoletniego do organizacji lub instytucji powołanej do przygotowania zawodowego albo do innej placówki sprawującej częściową pieczę nad dziećmi;

5) zarządzić umieszczenie małoletniego $w$ rodzinie zastępczej, rodzinnym domu dziecka albo $\mathrm{w}$ instytucjonalnej pieczy zastępczej albo powierzyć tymczasowo pełnienie funkcji rodziny zastępczej małżonkom lub osobie,

46 Ustawa z dnia 6 czerwca 1997 r. - Kodeks postępowania karnego, tekst jednolity: Dz. U. z 2018 r. poz. 1987 z późn. zm. (dalej: k.p.k.). 
niespełniającym warunków dotyczących rodzin zastępczych, w zakresie niezbędnych szkoleń, określonych w przepisach o wspieraniu rodziny i systemie pieczy zastępczej albo zarządzić umieszczenie małoletniego w zakładzie opiekuńczo-leczniczym, w zakładzie pielęgnacyjno-opiekuńczym lub w zakładzie rehabilitacji leczniczej.

Sąd opiekuńczy może również pozbawić władzy rodzicielskiej, jeżeli władza rodzicielska nie może być wykonywana z powodu trwałej przeszkody albo jeżeli rodzice nadużywają władzy rodzicielskiej lub w sposób rażący zaniedbują swe obowiązki względem dziecka (art. 111 k.r.o.).

Dobro dziecka jest fundamentalną zasadą polskiego prawa rodzinnego. Piecza nad dzieckiem oznacza bowiem „roztaczanie stałej troski i starań o dziecko, obejmuje troskę o zapewnienie dziecku odpowiednich warunków egzystencji, ochronę przed niebezpieczeństwami mogącymi zagrozić dziecku oraz zapewnienie prawidłowego rozwoju (art. 92 k.r.o.)" ${ }^{\prime 47}$.

Sąd rodzinny zgodnie $z$ art. 7 § 1 u.p.s.n. może:

1) zobowiązać rodziców lub opiekuna do poprawy warunków wychowawczych, bytowych lub zdrowotnych nieletniego, a także do ścisłej współpracy ze szkołą, do której nieletni uczęszcza, poradnią psychologiczno-pedagogiczną lub inną poradnią specjalistyczną, zakładem pracy, w którym jest zatrudniony, oraz lekarzem lub zakładem leczniczym;

2) zobowiązać rodziców lub opiekuna do naprawienia w całości lub w części szkody wyrządzonej przez nieletniego.

Sąd może wreszcie zwrócić się do właściwych instytucji państwowych lub społecznych oraz jednostek samorządowych o udzielenie niezbędnej pomocy w poprawie warunków wychowawczych, bytowych lub zdrowotnych nieletniego (art. $7 \S 2$ u.p.s.n.).

Jeżeli rodzice uchylają się od wykonania obowiązków nałożonych na nich przez sąd rodzinny, sąd ten może wymierzyć im karę pieniężną w wysokości od 50 do 1500 złotych (art. 8 u.p.s.n.).

W literaturze przyjmuje się słusznie, że przez uchylanie się od wykonywania obowiązków nałożonych przez sąd rodzinny należy

rozumieć wyłącznie uchylanie się od tych obowiązków, które zostały nałożone na podstawie ustawy o postępowaniu w sprawach nieletnich. Przyjmuje się, że chodzi tu nie tylko o obowiązki nałożone na rodziców lub opiekuna

47 Z. Wrona, Odpowiedź podsekretarza stanu... 
nieletniego na podstawie art. 7 § 1 u.p.s.n., ale także o niewykonywanie albo wadliwe wykonywanie nadzoru odpowiedzialnego rodziców (art. 6 pkt 3 u.p.s.n.), w tym również nieskładanie sprawozdań dotyczących przebiegu tego nadzoru ${ }^{48}$.

\section{Wnioski}

Od kiedy zatem dziecko może samo pozostać w domu, samo podróżować? Zgodnie z przepisami dziecko, które nie ukończyło 7 lat nie może samo przebywać poza domem, na drodze publicznej. Jeżeli taka sytuacja nastąpi, rodzice powinni liczyć się z interwencją organów państwa i ponoszeniem odpowiedzialności karnej za popełnienie przestępstwa lub wykroczenia.

Rodzice ponoszą odpowiedzialność za dziecko aż do ukończenia przez nie 18 roku życia. Są jednak sytuacje, gdy rodzic pozostawia samo dziecko w domu np. na chwilę gdy wyrzuca śmieci, idzie do piwnicy czy do lokalnego sklepu. Zdarza się, że dziecko zostaje samo w czasie, gdy jeden z rodziców wraca z pracy, a drugi idzie do pracy. Jaka jest odpowiednia granica wieku, aby dziecko mogło przebywać samo w domu - 10, 13 lat?

Na tak postawione pytanie trudno znaleźć jednoznaczną odpowiedź w przepisach prawnych. Mówią one jedynie o granicy 7 lat i przebywaniu dziecka poza domem. Można jednak posiłkować się nimi i skoro przepisy pozwalają ośmiolatkowi na samodzielnie poruszanie się po ulicy, to tym bardziej może pozostać sam w domu. Rodzic jednak powinien kierować się rozsądkiem, brać pod uwagę rozwój umysłowy swojego dziecka. Czasami sześciolatek wykazuje większą dojrzałość niż niejeden trzynastolatek. Przede wszystkim rodzice powinni rozmawiać z dziećmi i wyjaśniać im okoliczności, które mogą stanowić zagrożenie oraz to jak powinny się zachować w sytuacji kryzysowej, np. pożar, jaki jest numer telefonu do służb ratunkowych ${ }^{49}$.

48 A. Haak-Trzuskawska, H. Haak, Ustawa o postępowaniu w sprawach nieletnich. Komentarz, Warszawa 2015, Legalis; K. Grześkowiak [w:] A. Krukowski (red.), Ustawa o postępowaniu w sprawach nieletnich. Komentarz, Warszawa 1991, s. 59; Uchwała Sądu Najwyższego (7) - zasada prawna z dnia 19 czerwca 1984 r., III CZP 19/84, OSNCPiUS 1985, nr 2/3, poz. 19.

49 Od kiedy dziecko może zostać samo w domu?, https://www.sosrodzice.pl/dziecko -moze-zostac-samo-domu/ [dostęp: 13.11.2018 r.]. 
Nie można też ograniczać dziecka, gdyż (np. poprzez samodzielne podróże komunikacją miejską) uczy się samodzielności, oszczędności, punktualności, nabierają pewności siebie - są aktywne ${ }^{50}$.

Słowa kluczowe: dziecko, rodzice, władza rodzicielska, odpowiedzialność rodziców, porzucenie

\section{Bibliografia}

Bojarski M., W. Radecki, Kodeks wykroczeń. Komentarz, Warszawa 2013.

Bojarski T., A. Michalska-Warias, J. Piórkowska-Flieger, M. Szwarczyk, Kodeks karny. Komentarz, Warszawa 2009.

Brylak J., Ochrona prawna bezpieczeństwa w ruchu drogowym, Warszawa 2018.

Celejewska E., Jeden z najprostszych sposobów, by nauczyć dziecko samodzielności $i$ pewności siebie, http://ohme.pl/lifestyle/jeden-najprostszych-sposobow-by-nauczyc-dziecko-samodzielnosci-pewnosci [dostęp: 13.11.2018 r.].

Czy moje dziecko może samo lecieć liniami Emirates?, https:/ / www.emirates.com/ $\mathrm{pl} /$ polish/help/faq/193411/can-my-child-travel-alone-on-an-emirates-flight [dostęp: 14.01.2019 r.].

Dzieci podróżujace samodzielnie - mali pasażerowie to wielka sprawa!, https://www. lufthansa.com/pl/pl/dzieci-podrozujace-same [dostęp: 14.01.2019 r.].

Egierska D., Zapobieganie demoralizacji nieletnich (Wokót art. 105 k.w.), ,ZZagadnienia Wykroczeń" 1973, nr 1, s. 65-68.

Głowacka A., Nienależyte sprawowanie opieki. Odpowiedzialność odszkodowawcza opiekuna, „Acta Erasmiana” 2015, t. 10, s. 249-272.

Grześkowiak A., K. Wiak (red.), Kodeks karny. Komentarz, Warszawa 2012.

Grześkowiak A., Prawna odpowiedzialność rodziców za zaniedbania wychowawcze, „Ruch Prawniczy, Ekonomiczny i Socjologiczny" 1985, z. 1, s. 111-128.

Haak-Trzuskawska A., H. Haak, Ustawa o postępowaniu w sprawach nieletnich. Komentarz, Warszawa 2015.

Hendrych K., Wykonywanie wtadzy rodzicielskiej i kontaktów w warunkach istnienia elementu zagranicznego, Warszawa 2016.

Jaros P.J., M. Michalak (oprac.), Prawa dziecka. Dokumenty Organizacji Narodów Zjednoczonych, Warszawa 2015.

50 E. Celejewska, Jeden z najprostszych sposobów, by nauczyć dziecko samodzielności i pezwności siebie, http:/ / ohme.pl/lifestyle/jeden-najprostszych-sposobow-by-nauczyc-dziecko-samodzielnosci-pewnosci [dostęp: 13.11.2018 r.]. 
Kaczmarek M., Standardy prawa rodzinnego - zagadnienia prawne dotyczace dziecka i rodziny. Materiaty szkoleniowe dla osób pracujacych z dzieckiem i rodzina, http:/ / www.frs.pl/docs/pr_kaczmarek.pdf [dostęp: 13.11.2018 r.].

Kalitowski M., Kodeks wykroczeń a ochrona nieletniego i małoletniego, "Zagadnienia Wykroczeń" 1972, nr 2, s. 44-54.

Kalitowski M., Ochrona dziecka w kodeksie wykroczeń (Z badań nad wykroczeniami, których popetnienie wiąże się z osoba nieletniego lub małoletniego), "Zagadnienia Wykroczeń" 1979, nr 1, s. 1-8.

Kids Solo, https://www.airfrance.pl/PL/pl/common/guidevoyageur/assistance/enfant_seul_um.htm [dostęp: 14.01.2019 r.].

Kilińska-Pękacz A., Ochrona dzieci w kodeksie wykroczeń, „Studia z Zakresu Prawa, Administracji i Zarządzania Uniwersytetu Kazimierza Wielkiego w Bydgoszczy" 2012, t. 1, s. 205-218.

Kilińska-Pękacz A., Przestępstwo porzucenia dziecka, „Prokuratura i Prawo” 2016, nr 4 , s. 22-34.

Kosonoga J., Glosa do wyr. SN z 3.4.2008 r., IV KK 471/07, „Wojskowy Przegląd Prawniczy" 2010, nr 1, s. 143-150.

Krukowski A. (red.), Ustawa o postępowaniu w sprawach nieletnich. Komentarz, Warszawa 1991.

Kwiatek M., 510 rodziców zostało aresztowanych za pozostawienia dzieci samych w domu w 2015 roku, http://www.anglia.today/dziecko/510-rodzicow-zostalo-aresztowanych-za-pozostawienie-dzieci-samych-w-domu-w-2015-roku [dostęp: 13.11.2018 r.].

Od kiedy dziecko może zostać samo w domu?, https:/ / www.sosrodzice.pl/dziecko-moze-zostac-samo-domu/ [dostęp: 13.11.2018 r.].

Piasecki K. (red.), Kodeks rodzinny i opiekuńczy. Komentarz, Warszawa 2011.

Pietrzykowski K. (red.), Kodeks rodzinny i opiekuńczy. Komentarz, Warszawa 2012.

Podróż dziecka bez opiekuna, https://www.lot.com/pl/pl/podroz-dziecka-bez-opiekuna [dostęp: 13.11.2018 r.].

Podróż dziecka bez opiekuna w samolocie, https:/ / www.esky.pl/porady-dla-podroz-nych/loty/dziecko-w-samolocie/podroz-dziecka-bez-opiekuna-w-samolocie [dostęp: 14.01.2019 r.].

Powszechny Zakład Ubezpieczeń, Wspótczesny świat dziecka. Diagnoza, https:/ / nie-straszki.pzu.pl/files/raport_pzu_bezpieczne_dziecko.pdf [dostęp: 13.11. 2018 r.].

Przestępstwa przeciwko rodzinie i opiece (206-211), http:/ / statystyka.policja.pl/st/ kodeks-karny/przestepstwa-przeciwko-7/63510,Porzucenie-maloletniego-albo-osoby-nieporadnej-art-210.html [dostęp: 13.11.2018 r.].

Report of the Consultation on Child Abuse Prevention [Raport z konsultacji nad zapobieganiem krzywdzeniu dzieci], Światowa Organizacja Zdrowia, Genewa 1999, http:/ / fdds.pl/baza_wiedzy/zaniedbywanie-dzieci/ [dostęp: 13.11.2018 r.]. 
Safjan M. (red.), Standardy Prawne Rady Europy. Teksty i komentarze, t. 1. Prawo rodzinne, Warszawa 1994.

Sam w domu! Od jakiego wieku dziecko może zostać bez opieki?, https:/ / www.familie. pl/artykul/Sam-w-domu-Od-jakiego-wieku-dziecko-moze-zostac-bez-opieki,12164,2.html [dostęp: 13.11.2018 r.].

Sienkiewicz Z., Kilka uwag o wykroczeniu z art. 105 k.w., "Zagadnienia Wykroczeń" 1985, nr 4/5, s. 45-50.

Smyczyński T. (red.), System Prawa Prywatnego, t. 12. Prawo rodzinne i opiekuńcze, Warszawa 2011.

Stefański R.A. (red.), Kodeks karny. Komentarz, Warszawa 2018.

Stolarska W., Od kiedy dziecko może zostać samo w domu?, https:/ / dziecko.trojmiasto.pl/Od-kiedy-dziecko-moze-zostac-samo-w-domu-n115447.html [dostęp: 13.11.2018 r.].

System opieki nad małoletnimi w Republice Irlandii (stan prawny na dzień 1 kwietnia 2014 r.), https://www.msz.gov.pl/resource/966a55f8-56cb-4f8b-bc40-4fa259be1861:JCR [dostęp: 13.11.2018 r.].

Szymańczak J., Europejska konwencja o wykonywaniu praw dzieci jako kolejny element prawnej ochrony dzieci, "Informacja Biura Studiów i Ekspertyz” 1996, nr 377, s. 1-16.

Ustuga asysty dla dzieci podróżujących bez opieki (Unaccompanied Minor), https:/ / www.klm.com/travel/pl_pl/prepare_for_travel/travel_planning/children/umnr_yp_framed.htm [dostęp: 14.01.2019 r.].

Wrona Z., Odpowiedź podsekretarza stanu w Ministerstwie Sprawiedliwości - z upoważnienia ministra - na zapytanie nr 4059 w sprawie odpowiedzialności rodziców i opiekunów prawnych za dzieci, często będace ofiarami ich nierozwagi i braku odpowiedzialności, Warszawa, 17 czerwca 2009 r., http:/ / orka2.sejm.gov.pl/IZ6. nsf/main/2D0DB8A3 [dostęp: 13.11.2018 r.].

\section{PARENTS' RESPONSIBILITY FOR LACK OF CHILDCARE}

\section{Sum mary}

Parents, in accordance with the provisions of the Family and Guardianship Code, are responsible for the care of their child up to the age of majority. However, parents do not always fulfil their duties related to childcare tasks properly, e.g. they lead to negligence, leave the child without proper care. As a consequence, they may be held criminally liable for the child's jeopardize or abandonment.

Parents are responsible for their child up to the age of 18 . However, there are situations when the parent leaves the child alone at home, e.g. for a moment when he or she throws away rubbish, goes to the basement or a local shop. It happens 
sometimes that a child stays alone when one of the parents went to work and the other did not manage to return yet.

However, a parent should use reason and take into account the mental development and maturity of his or her child. First of all, parents should talk to their children and explain them situations that may pose a threat, as well as they should behave in a crisis situation, e.g. a fire, such as the emergency telephone number.

Key words: child, parents, parental authority, parental responsibility, abandonment

\section{ОТВЕТСТВЕННОСТЬ РОДИТЕЛЕЙ ЗА ОТСУТСТВИЕ УХОДА ЗА РЕБЕНКОМ}

\section{Резюме}

Родители, в соответствии с положениями Семейного и опекунского кодекса, несут ответственность за присмотр за ребенком в возрасте до совершеннолетия. Родители, однако, не всегда должным образом выполняют свои обязанности, связанные с уходом и воспитанием ребенка, например, пренебрегают уходом, оставляют ребенка без должного ухода. Как следствие, они могут быть привлечены к уголовной ответственности за то, что подвергли ребенка опасности или оставлению.

Родители несут ответственность за ребенка до достижения им 18 лет. Однако бывают ситуации, когда родитель оставляет ребенка одного дома, например, на момент, когда он выбрасывает мусор, идет в подвал или в местный магазин. Бывает, что ребенок остается один между тем, когда один из родителей уже ушел на работу, а другой еще не вернулся.

Родитель однако должен руководствоваться разумом, учитывать зрелость и умственное развитие своего ребенка. Прежде всего, родители должны поговорить с детьми и объяснить им ситуации, которые могут представлять угрозу, и как они должны вести себя в кризисной ситуации, например, при пожаре, какой номер телефона экстренной помощи.

Ключевые слова: ребенок, родители, родительская власть, родительская ответственность, оставление 
